\title{
B lymphocyte alloantigens in the study of the genetic basis of rheumatoid arthritis
}

\author{
G. S. PANAYI AND P. H. WOOLEY \\ From the Department of Medicine and Arthritis Research Unit, Guy's Hospital Medical School, London \\ SE1 9RT
}

SUMMARY In order to carry out tissue typing studies in patients with rheumatoid arthritis (RA), 116 sera from pregnant multiparous women were screened for cytotoxicity specific for B lymphocytes. It was possible to identify three sera (M55, M58, M87) which reacted specifically with B cells after absorption with platelets. Each appeared to have a different specificity which was presumed to correspond to an alloantigen marker on the lymphocyte surface. The frequency of these alloantigen markers on B lymphocytes was investigated in patients with classical or definite RA and in controls. One of these, M58, occurred in 32 out of 43 RA patients (74.4\%) compared with 10 out of 37 controls $(27 \%)$. This difference was highly significant $(\mathrm{P}<0.0005)$. The relative risk of developing RA is 7.85 times greater in those possessing alloantigen M58. The other two B cell alloantigens failed to show any association with RA. The association with M58 may indicate a significant genetic contribution to disease susceptibility in RA.

Since the discovery of the association of HLA B27 with ankylosing spondylitis (Brewerton et al., 1973) an HLA association has been sought in rheumatoid arthritis (RA). This search has proved unsuccessful (Seignalet et al., 1972; Lies et al., 1972) except for the association between RA and B27 reported from Finland (Isomaki et al., 1975). Recently, the emphasis has shifted from the HLA A, B, and C series to other identified genetic loci within the major histocompatibility complex on chromosome 6 , such as the HLA D locus as defined by the mixed lymphocyte reaction (MLR). Evidence from studies in the mouse suggest that immune response (Ir) genes are present in this region of the complex (David, et al., 1973; Wernet, 1976). Ir genes code for immune associated (Ia) antigens which are particularly expressed on the surface of B lymphocytes (Winchester et al., 1975). Recently, multiple sclerosis has been found to have a strong association with such $B$ cell alloantigens (Terasaki et al., 1976; Compston et al., 1976).

In RA the presence of an antigen associated with the HLA D locus has been suggested because of weak MLR between homologous RA lymphocyte populations (Astorga and Williams, 1969; Stastny, 1974). However, since this finding may be open to other interpretations (Keystone et al., 1976) we have

Accepted for publication March 21, 1977

Correspondence to Dr. G. S. Panayi searched for an association between a B lymphocyte alloantigen and RA, and report one such strong association.

\section{Patients}

Forty-three patients were selected for study who had classical or definite RA (Ropes et al., 1959). The 37 controls consisted of patients with degenerative joint or spinal disease and laboratory personnel.

\section{Materials and methods}

SERA

Sera were obtained from 116 multiparous women, each with a minimum of three pregnancies, and stored at $-20^{\circ} \mathrm{C}$.

\section{B AND T LYMPHOCYTES}

Lymphocytes were prepared according to the method of Compston et al. (1976) except that $T$ rosettes were formed using sheep red blood cells that had been treated with neuraminidase $(0.05$ units $/ 10 \mathrm{ml}$ of $10 \%$ red cells).

\section{CYTOTOXICITY TEST}

A direct, complement-mediated lymphocyte cytotoxicity test was used. $2 \mu l$ of antiserum was incubated with a similar volume of cell suspension $\left(2 \times 10^{6}\right.$ 
cells $\mathrm{ml}^{-1}$ ) at $20^{\circ} \mathrm{C}$ for 1 hour, in $10 \mu \mathrm{l}$ well Terasaki plates. $2 \mu \mathrm{l}$ rabbit complement was added, and incubation continued at $20^{\circ} \mathrm{C}$ for 1 hour. Plates were incubated for a final 20 minutes at $37^{\circ} \mathrm{C}$, then viability assayed using $0.4 \%$ trypan blue. Background cell death was $5-20 \%$ and tests were repeated if it exceeded $20 \%$. A particulaı serum was considered cytotoxic for cells if killing was greater than $35 \%$ above background cell death.

\section{PRELIMINARY SCREENING OF SERA}

$B$ cell specific antisera with a possible RA association were provisionally identified by screening the 116 sera against cell suspensions enriched for B lymphocytes from 22 RA patients and 17 normals. Sera were selected for further study if they killed the same proportion of cells in individual samples of lymphocytes as were known to bear surface immunoglobulins determined by immunofluorescence with antihuman Ig (Weir, 1973). Sera were sought which reacted more frequently with cells from RA patients than from normal individuals.

\section{ABSORPTION OF SERA}

Selected sera were absorbed with platelets to remove antibodies directed against HLA A, B, and C determinants. Sera were absorbed three times at $4^{\circ} \mathrm{C}$ using platelets obtained from the RA patients and controls used in the study, and from the Blood Transfusion Unit. A total of $10^{10}$ platelets per $\mathrm{ml}$ of serum was used. After absorption, sera were not cytotoxic for $\mathrm{T}$ lymphocytes.

\section{B CELl ALlOANTIGEN TYPING}

$T$ and $B$ cell preparations from the same blood sample were tested in parallel. Tests were run without awareness of the diagnostic category of the lymphocyte donors, with both RA patients and controls being included in each test.

\section{Results}

PURITY OF ENRICHED LYMPHOCYTE PREPARATIONS T lymphocyte-enriched populations were better than $80 \%$ pure as assessed by rosette formation with sheep red blood cells. The B lymphccyte preparo tions varied in purity from $50-75 \%$. This was determined by immunofluorescent staining fo surface immunoglobulin and by microcytotoxicito assay using sheep antihuman immunoglobuliō serum and rabbit complement. The results from the two tests were comparable.

PRELIMINARY SCREENING OF PREGNANCY SERA Preliminary screening showed that 62 of the 116 sera failed to react with any of the B-enriched celf preparations. The sera which did show cytotoxicite fell into one of two categories, moderate activi with small numbers of either controls or RA groups or strong reactivity with the majority of the cePP preparations. The specificity of these sera is currenttes being investigated after absorption with platelet\& Three sera (coded M55, M58, and M87) satisfied the original selection criteria and were used in subsequent studies.

SPECIFICITY OF PLATELET ABSORBED SERA FO B LYMPHOCYTES

Sera M55, 58, and 87 were rendered free of lymphocyte cytotoxicity by exhaustive absorption with platelets (see Materials and methods). Neveo theless parallel cytotoxicity experiments were performed with each serum on the $\mathrm{T}$ and $\mathrm{B}$ lymph cyte-enriched cell preparations from each donor. 番 no case was there killing of $T$ lymphocytes. The percentage of B lymphocytes killed varied from 46 to $80 \%$. However, the percentage of killing was similar to the proportion of $\mathbf{B}$ cells present in the $\mathbf{B}$ cell enriched population (Table 1). It is concludee from these results that not only were the absorbed sera specific for B ce'ls but also that they killed the majority of such cells in each positive cytotox assay.

REACTIVITY OF PLATELET ABSORBED SERA WIT LYMPHOCYTES FROM PATIENTS WITH RA AN NORMAL CONTROLS

A 'chequer-board' pattern of cytotoxicity waㄱ constructed (Table 2). Different reactivity pattern were seen when the B lymphocyte-specific sera M5

Table 1 Relationship between killing of lymphocytes by absorbed sera and the proportion of B lymphocytes in enriched cell population (mean $\pm I S D$ )

\begin{tabular}{|c|c|c|c|c|c|}
\hline \multirow[t]{2}{*}{ Lymphocyte donors } & \multicolumn{3}{|c|}{$\%$ Killing with $B$ cell specific sera } & \multirow{2}{*}{$\begin{array}{l}\% \text { B cells } \\
\text { (surface Ig) }\end{array}$} & \multirow{2}{*}{$\begin{array}{l}\% B \text { cells } \\
(\text { anti-Ig }+C \text { killing })\end{array}$} \\
\hline & M55 & $M 58$ & $M 87$ & & \\
\hline RA & $49 \cdot 0 \pm 15 \cdot 3$ & $50 \cdot 0 \pm 15 \cdot 3$ & $64 \cdot 0 \pm 20 \cdot 0$ & $45 \cdot 6 \pm 8 \cdot 9$ & $51 \cdot 0 \pm 8 \cdot 0$ \\
\hline Normals & $50 \cdot 0 \pm 7 \cdot 1$ & $52 \cdot 1 \pm 11 \cdot 7$ & $68 \cdot 0 \pm 15 \cdot 5$ & $47 \cdot 5 \pm 14 \cdot 6$ & $53 \cdot 0 \pm 10 \cdot 6$ \\
\hline
\end{tabular}

Ig =immunogobulin; $\mathrm{C}=$ complement. 
M58, and M87 were tested against the cells from 43 patients and 37 control subjects. It therefore appears that the three sera are detecting different cell-surface structures on B lymphocytes. This is especially true of the patients with RA. However, it is interesting to note that the reaction patterns of sera M58 and M87 are significantly similar in the panel of normal subjects $\left(\chi^{2}=5.19 ; P<0.05\right)$ but not in the RA panel, in that the distribution of positive reactions of M58 is almost completely included within that of M87.

The reaction of these sera with B lymphocyteenriched preparations from RA and normals is summarized in Table 3. The first antiserum, M55, is cytotoxic to a similar degree with B cells from either RA (25.6\%) or controls (21.6\%). Antiserum M87 killed $B$ cells from $37 \cdot 1 \%$ of controls and from

Table $2 B$ cell alloantigen typing results

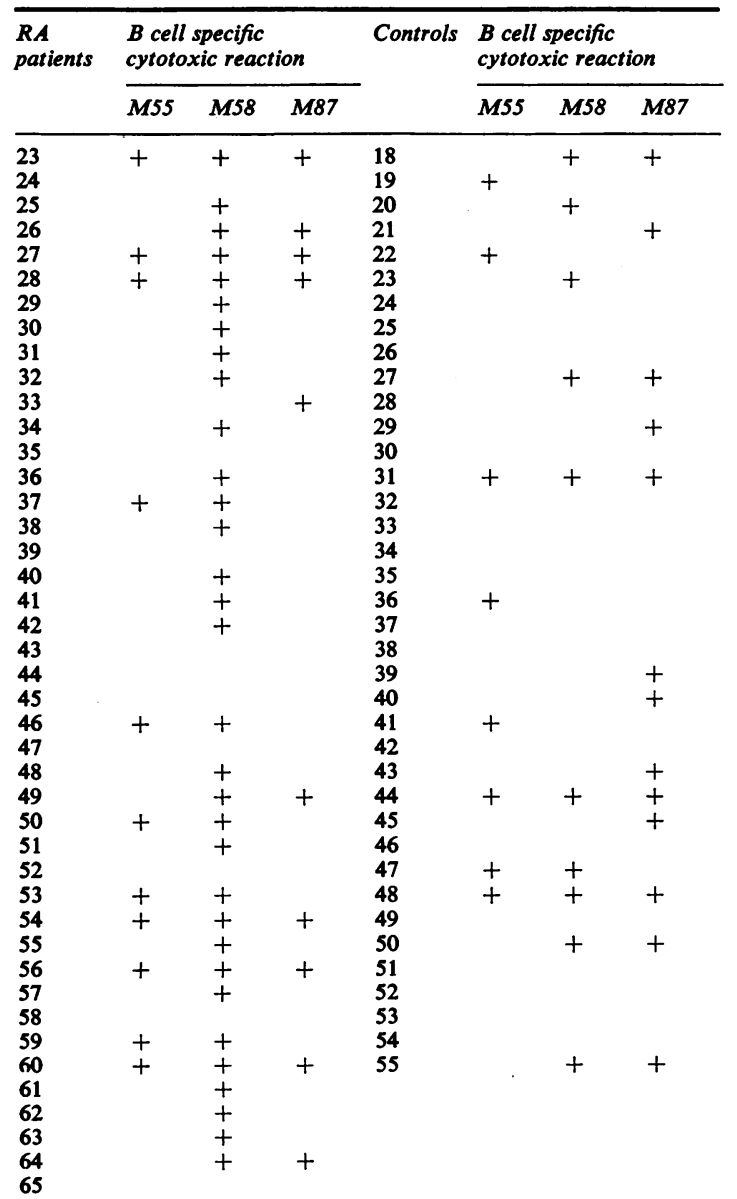

$+=$ Positive cytotoxicity.
Table 3 Frequency of killing of $B$ cells by specific sera in controls and $R A$ patients

\begin{tabular}{|c|c|c|c|c|c|c|c|}
\hline \multirow{3}{*}{$\begin{array}{l}\text { Pregnancy } \\
\text { serum }\end{array}$} & \multicolumn{4}{|c|}{ Killing of B lymphocytes } & \multirow[t]{3}{*}{$\chi^{2}$} & \multirow{3}{*}{$\begin{array}{l}P \text { value } \\
\text { (uncorrected) }\end{array}$} & \multirow{3}{*}{$\begin{array}{l}\text { Relative } \\
\text { risk }\end{array}$} \\
\hline & \multicolumn{2}{|c|}{$\begin{array}{l}\text { Controls } \\
\text { (37) }\end{array}$} & \multicolumn{2}{|c|}{$\begin{array}{l}\text { RA patients } \\
\text { (43) }\end{array}$} & & & \\
\hline & $n$ & $\%$ & $n$ & $\%$ & & & \\
\hline $\begin{array}{l}\text { M55 } \\
\text { M58 } \\
\text { M87 }\end{array}$ & $\begin{array}{r}8 \\
10 \\
14\end{array}$ & $\begin{array}{l}21.6 \\
27.0 \\
37.1\end{array}$ & $\begin{array}{l}11 \\
32 \\
10\end{array}$ & $\begin{array}{l}25 \cdot 6 \\
74 \cdot 4 \\
23 \cdot 3\end{array}$ & $\begin{array}{c}0.177 \\
17.81 \\
2.01\end{array}$ & $\begin{array}{l}\text { NS } \\
0 \cdot 0005 \\
\text { NS }\end{array}$ & $\begin{array}{l}1.25 \\
7.85 \\
0.50\end{array}$ \\
\hline
\end{tabular}

$\chi^{2}$ calculated for a $2 \times 2$ contingency table: one degree of freedom. NS = not significant. Relative risk is calculated according to the method of Svejgaard et al. (1975).

$23.3 \%$ of RA patients. This difference was not significant. However, serum M58 killed more B lymphocyte preparations from RA patients than from controls. The alloantigen presumed to be detected by this serum occurs with a freqnecy of $\mathbf{7 4 . 4 \%}$ in RA patients compared with $27.0 \%$ in the control group. This represents a highly significant difference with a probability of $\mathbf{P}<0 \cdot 0005$.

It can be calculated that the relative risk of developing RA in those possessing alloantigen M58 is 7.85 times greater than in those not possessing this marker. The frequency of M58 in the RA group was independent of disease activity, rheumatoid factor status, or prescribed drugs.

\section{Discussion}

Using specifically absorbed pregnancy sera, three B lymphocyte alloantigens have been provisionally identified by microcytotoxicity assay. They have been coded M55, M58, and M87. Our data show M58 to be present in $74.4 \%$ of RA patients compared with $27 \%$ of controls. This is a highly significant difference.

This study has therefore defined an antigen present specifically on B lymphocytes identified by cytotoxic sera which have been absorbed and are unreactive against $T$ cells. Such $B$ cell alloantigens in the mouse are thought to be immune associated (Ia) antigens, the molecular expression of immune response (Ir) genes. It may therefore be tentatively suggested that the association which has been shown is that of RA with an Ia determinant. However, before this explanation can be accepted it must be shown that the transmission of these antigens is related to other gene products of the MHC region. Since no association has been shown between HLA antigens and RA this question can only be answered by family studies. These are now in progress.

Characteristically, patients with RA display many immunological abnormalities the basis for which 
and the development of the disease itself may be due to the possession of this Ia antigen. It may be speculated that an antigenic trigger, such as a virus, may be necessary in addition to the possession of this Ia antigen.

Alternative explanations for these results are possible. First, these antigens could be the cellsurface expression of virus infection of B lymphocytes. This seems untenable as one would have to postulate that three pregnancy sera selected at random detect three separate viral antigens present on B cells from normal individuals as well as patients with RA. Second, the increased frequency of cytotoxicity by M58 could be due to factors adsorbed on to the lymphocyte surface from RA sera. This also seems unlikely since reactivity with serum M58 was not related to disease activity and since $27 \%$ of normal subjects also reacted with this serum. Furthermore one would have to assume that three such factors are present in RA and normal sera and are adsorbed on to B cells in order to account for the results. It appears therefore that the simplest explanation is that these sera do indeed detect alloantigens expressed on the surface of $B$ lymphocytes.

The occurrence of M58 in only $74.4 \%$ of RA cases might have two explanations. The first is that M58 is not the true disease marker for RA but is closely linked to it so that as a result of linkage disequilibrium some $25 \%$ of RA patients do not possess this marker. Alternatively the disease termed 'RA' may represent a group of diseases of differing aetiology, not all of which are associated with M58.

The similar reactive patterns of sera M58 and M87 in the normal subjects need explanation. Two are possible. First that serum M87 contains a cross-reactive antibody of which there are many examples in HLA A, B, and C serology or, second, that it detects an antigen usually found in association with that defined by serum M58 (cf HLA A1 and B8). The latter explanation seems more likely since the reactivity of RA lymphocytes with M87 is markedly reduced when compared to that of the normal subjects. It may be speculated that since the incidence of reactions with M58 is increased while that with M87 is decreased in RA patients, that these two sera may be detecting B cell alloantigens which are the product of an Ir gene complex.

We hope that family studies, investigations of disease subgroups, D-locus typing, and further alloantigen investigations will clarify the association of this antigen with RA. It may be concluded, howeve्g, that these results may indicate that a genetic basis exists for the development of RA.

We thank Professors J. R. Batchelor and M. Lessôf for their help and encouragement, and the staff $\overline{\overline{c o f}}$ the McNair Centre for providing the pregnancy se零. The work was financed with a grant from the Arthritis and Rheumatism Council.

\section{References}

Astorga, G. P., and Williams, R. C. Jr. (1969). Altered reactivity in mixed lymphocyte culture of lymphocytes from patients with rheumatoid arthritis. Arthritis and Rheumatism, 12, 547-554.

Brewerton, D. A., Caffrey, M., Hart, F. D., James, D. C. Æ్ Nicholls, A., and Sturrock, R. D. (1973). Ankylosify spondylitis and HL-A 27, Lancet, 1, 904-907.

Compston, D. A. S., Batchelor, J. R., and McDonald, W (1976). B-lymphocyte alloantigens associated with multipe sclerosis. Lancet, 1, 1261-1265.

David, C. S., Shreffler, D. C., and Frelinger, J. A. (1979). New lymphocyte antigen system (Lna) controlled by the Ir region of the mouse $\mathrm{H}-2$ complex. Proceedings of tte National Academy of Sciences of the USA, 70, 2509-2514.

Isomaki, H., Koots, K., Martis, J., Niosila, M., and Tiintkainen, A. (1975). HL-A 27 and arthritis. Annals of Clinical Research, 7, 138-145.

Keystone, E. C., Gladman, D. D., Urowitz, M. B., amd Clarke, D. A. (1976). Mixed lymphocyte reaction (ML in rheumatoid arthritis: dose-response kinetics. Clinigl Immunology and Immunopathology, 5, 320-325.

Lies, R. B., Messner, R. P., and Troup, G. M. (19724.

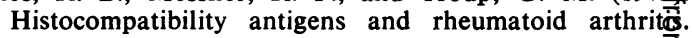
Arthritis and Rheumatism, 15, 524-529.

Ropes, M. W., Bennett, G. A., Cobb, S. Jacox, R., a丽 Jessar, R. A. (1959). Diagnostic criteria for rheumatơd arthritis. Annals of the Rheumatic Diseases, 18, 49-53.

Seignalet, D. A., Clot, J., Sany, J., and Serre, H. (1972). HL-A antigens in rheumatoid arthritis. Vox Sanguinis, 23 , 468-473.

Stastny, P. (1974). Mixed lymphocyte culture typing cells from patients with rheumatoid arthritis. Tissue Antigeg, 4, 571-579.

Svejgaard, A., Hauge, M., Jersild, G., Platz, P., Ryder, L. $\stackrel{乛}{\text { f., }}$ Staub Neilson, L., and Thomsen, M. (1975). The HEA System, Monographs in Human Genetics, Vol. 7. Baste. Terasaki, P. I., Park, M. S., Opelz, G., and Ting, A. (1976. Multiple sclerosis and high incidence of a B lymphocyte antigen, Science, 193, 1245-1247.

Weir, D. M. (1973). Immunochemistry, Vol. 1. Blackwejlb Oxford.

Wernet, P. (1976). Human Ia-type alloantigens: methods detection, aspects of chemistry and biology, markers fof disease states. Transplantation Reviews, 30, 271-298.

Winchester, R. J., Fu, S., Wernet, P., Kunkel, H. G., Dupoif?, B., and Jersild, C. (1975). Recognition by pregnanळy serums of non-HL-A alloantigens selectively expressed $\$$ B lymphocytes. Journal of Experimental Medicine, 14 924-929. 